$\begin{array}{ll}\text { Volume } & : 05 \\ \text { Nomor } & : 03 \\ \text { Bulan } & : \text { September } \\ \text { Tahun } & : 2019 \\ \text { http } & : \text { //ejurnal.pps.ung.ac.id/index.php/AKSARA/index }\end{array}$

\title{
MENINGKATKAN HASIL BELAJAR MELALUI METODE DISKUSI
}

\author{
Femi Asri Pakaya \\ SDN 10 Kabila \\ femiasripakaya@gmail.com \\ Received: 02 Juni 2019; Revised: 19 Juli 2019; Accepted: 25 Agustus 2019
}

\begin{abstract}
ABSTRAK
Penelitian ini bermaksud untuk mengetahui hasil belajar siswa kelas IV dalam pembelajaran IPS dengan menggunakan metode diskusi. Hasil penelitian ini diharapkan dapat bermanfaat bagi pengembangan mutu pendidikan di sekolah dasar. Subyek penelitian ini adalah siswa kelas IV SDN 10 Kabila yang berjumlah 22 siswa. Teknik yang digunakan adalah menggunakan metode diskusi dalam pembelajaran. Analisis data atau pengujian hipotesis dilakukan secara bertahap dan berkesinambungan pada setiap akhir pembelajaran. Data yang terkumpul dianalisis secara kuantitatif. Pelaksanaan penelitian dilakukan melalui dua tahap yakni kegiatan pembelajaran siklus I dan siklus II. Pada akhir pembelajaran dilakukan evaluasi dan refleksi untuk mengetahui keberhaislan pembelajaran. Berdasarkan data yang diperoleh pada kegiatan siklus I nilai hasil test evaluasi masih rendah yakni daya serap hanya 59,16\% yang mampu memahami mater yang dibelajarkan. Pada saat dilaksanakan siklus II ditemukan peningkatan yang signifikan yakni $77.4 \%$ yang sudah memahami materi pembelajaran. Dengan nilai capaian tersebut telah mencapai kriteria Ketuntasan Minimal (KKM) yakni 70\%Dengan demikian dapat disimpulkan bahwa kegiatan pembelajaran dengan menggunakan metode diskusi dapat memberikan dampak positif berupa peningkatan hasil belajar siswa.
\end{abstract}

Kata kunci: mutu, prestasi, pembelajaran

\section{PENDAHULUAN}

Interaksi dalam proses belajar mengajar, merupakan kontak dan komunikasi di antara dua orang, yakni antara guru (sipengajar) dan siswa (anak didik). Kontak dan komunikasi dimaksud merupakan hubungan yang bersifat edukatif, dan diarahkan pada pencapaian tujuan tertentu (Soetomo, 1993:11). Hubungan tersebut dapat dilakukan oleh guru secara maksimal dengan menggunakan berbagai ketrampilan, dengan maksud menggerakkan aktivitas siswa untuk membangun kemampuan yang dimiliki anak, dalam mencapai tujuan yang diharapkan, sebagai hasil dari proses belajar.

Tujuan belajar adalah pembentukan pemahaman, nilai dan sikap serta ketrampilan personal-sosial, kognitif dan instrumental (Ali Imron:1996:25). Olehnya tugas guru dalam melakukan proses belajar mengajar seharusnya dapat menciptakan lingkungan pembelajaran yang kondusif, dimana anak dapat belajar dengan baik. Dengan demikian interaksi dapat terjadi dan dikategorikan sebagai proses belajar mengajar, jika dapat menghasilkan suatu perubahan pada salah satu pihak yakni siswa sebagai sipembelajar, yang biasa disebut dengan hasil belajar.

Perubahan tersebut pada umumnya mencakup tiga aspek tingkah laku manusia yakni aspek kognitif, efektif dan psikomotor, yang mencakup perubahan tingkah laku baik yang sifatnya baru secara keseluruhan, dan merupakan pengalaman individu itu sendiri dalam 


$\begin{array}{ll}\text { Volume } & : 05 \\ \text { Nomor } & : 03 \\ \text { Bulan } & : \text { September } \\ \text { Tahun } & : 2019 \\ \text { http } & : \text { //ejurnal.pps.ung.ac.id/index.php/AKSARA/index }\end{array}$

interaksi yang dilakukan. Namun disisi lain bersamaan dengan kemajuan ilmu pengetahuan dan teknologi, pelaksanaan proses belajar mengajar menjadi lebih kompleks karena mengajar (guru), siswa dan bahan agar masih dipengaruhi oleh variabel yang lain. Variabel yang dimaksud antara

lain peran guru dalam mengajar. Apakah guru memiliki ketrampilan yang sesuai dengan materi yang diajarkan, apakah penggunaan metode sudah tepat, apakah sarana, media dan alat sudah cukup menunjang? Tentunya aspek-aspek yang telah disebutkan itu memerlukan ketrampilan yang memadai dalam pelaksanaannya dalam. Dan untuk penerapan aspek tersebut menuntut ketrampilan guru yang profesional. Selain itu, guru dna orang tua perlu memperhatikan kemampuan dasar yang dimiliki siswa, sehingga akan menjadi kerja sama antara orang tua, guru dan siswa. Guru dapat mengembangkan bakat dan minat yang dimiliki siswa, dan bukan memaksanakn kehendak orang tua atau guru. Demikian pula kemampuan dalam hal menerima bahan ajar, kedisiplinan, kemampuan melakukan penyesuaian dengan situasi lingkungan belajar, cukup dominan mempengaruhi hasil pembelajaran. Sedangkan bahan ajar dapat dipengaruhi oleh kemajuan ilmu pengetahuan dan teknologi yang semakin pesat.

\section{TINJAUAN PUSTAKA}

\section{Pengertian Hasil belajar Siswa}

Hasil Belajar siswa secara umum dapat diklasifikasikan menjadi tiga yakni kognitif, afaktif dan psikomotorik (Davies, 1986:97; Jarolimek dan foster, 1981:148) dalam Damayanti (1993:145). Ketiga ranah tersebut terkait satu sama lainnya. Masing-masing disusun dari tingkat yang sederhana sampai ke yang kompleks yaitu: 1) Ranah kognitif terdiri atas: (a) pengetahuan (knowledge) mencakup kemampuan ingatan tentang hal dengan fakta, peristiwa, pengertian, kaidah, teori, prinsip atau metode, (b) Pemahaman (Comprehentio) mencakup, kemampuan mengangkat arti dan makna yang dipelajari, (c) Penerapan (Application) mencakup kemampuan menerapkan metode dan kaidah untuk menghadapi masalah, (d) Analisis (analysis) mencakup, kemampuan untuk merinci, menghubungkan, mengartikan rincian saling menghubungkan antara satu bagian dengan bagian yang lain, $€$ sintesis (Syntesis) mencakup, kemampuan untuk menyatukan hal-hal yang tidak menyatu menjadi satu kesatuan yang utuh, (f) evaluasi (Evaluation) mencakup kemampuan membentuk pendapat tentang beberapa hal berdasarkan kriteria tertentu. 2) Ranah Afaktif terdiri dari: (a) Penerimaan (receiving) suatu kemampuan untuk menghadirkan kedirian pada suatu efek atau stimulus-stimulus yang ia terima (b) Pemberian tanggapan (responding) kemampuan memberikan harga terhadap fenomena benda atau kejadian (c) Pemberian nilai (valucing) ialah upaya untuk memadukan berbagai jenis nilai yang berbeda kemudian dibangun menjadi suatu sistem nilai. (e)

\section{Metode Diskusi}

Metode diskusi merupakan pengajaran metode yang mana guru memberikan suatu persoalan (masalah) pada murid diberikan secara bersama-sama untuk memecahkan masalah tersebut dengan teman-temannya. Dalam diskusi saling tukar-menukar informasi, menerima informasi, dapat pula mempertahankan pendapatnya dalam rangka pemecahan masalah yang dihadapi oleh siswa. Menurut Usman dan Setiawati (2000:24) "metode diskusi adalah suatu penyampaian pelajaran dimana guru bersama-sama dengan siswa mencari jalan pemecahan atau persoalan yang dihadapi. 
Untuk lebih efesien dan efektifitasnya pelaksanaan diskusi dalam meningkatkan minat siswa, maka hal-hal yang harus dilakukan oleh seorang guru adalah sebagai penunjuk jalan. Sutomo (1996:156) mengemukakan tugas guru dalam menerapkan metode diskusi dalam pembelajaran adalah sebagai berikut: (1) Menjelaskan kembali apa yang menjadi pokok permasalahan apabila ada gejala-gejala yang menyimpang dari pembahasan semula (2) Menyarankan gagasan baru dalam melihat masalah yang sedang didiskusikan (3) Menunjukkan aspek-aspek penting menjadi pokok dapat ditinjau dari segi pemecahan masalah (4) Merumuskan kembali pertanyaan seorang siswa dengan jalan memperjelas pendapat anak yang dapat dimengerti oleh peserta diskusi lain (5) Menyimpulkan semua yang telah dikemukakan siswa, dimana titik penemuannya dan perbedaannya dijelaskan kembali.

Menurut Alipandie (1998:85) bahwa: "tugas guru dalam diskusi mencakup 3 macam peranan penting yaitu (i) sebagai pengatur lalu lintas; (ii) sebagai dinding pengama dan (iii) sebagai penunjuk jalan. Dalam hal guru lebih mengefektifkan pembelajaran yang mengacu pada pemecahan masalah. Dan membimbing siswa dalam diskusi.

\section{Pengertian IPS.}

IPS merupakan suatu program pendidikan dan buka sub disiplin ilmu tersendiri, sehingga tidak akan ditemukan baik dalam nomenklatur filsafat ilmu, disiplin ilmu-ilmu sosial (social scince) maupun ilmu pendidikan (Sumantri 2001:89). Social scence Education Council (SSEC) dan National Council for social studies (NCSS) menyebut IPS sebagai social scence education dan social studies. Dengan kata lain IPS mengikuti cara padnang yang bersifat terpadu dari sejumlah mata pelajaran. Menurut Gros (Kosasih Djahri,1981.h.I), ilmu social.

Merupakan disiplin intelektual yang mempelajari manusia sebagai makhluk sosial secara ilmiah, merumuskan pada manusia sebagai anggota masyarakat dan pada kelompok atau masyarakat yang ia bentuk. IPS sebagai satu program pendidikan tidak hanya menyajikan tentang konsep-konsep pengetahuan semata, namun harus pula mampu membina peserta didik menjadi warga masyarakat yang tahu akan hak dan kewajiban, yang juga memiliki tanggung jawab atas kesejahteraan bersama yang seluas-luasnya. Oleh karena peserta didik yang dibina melalui IPS tidak hanya memiliki pengetahuan dan kemampuan berpikir tinggi, namun peserta didik diharapkan pula memiliki kesabaran dan tanggung jawab yang tinggi terhadap diri dan lingkungannya.

\section{Pokok-Pokok Materi Keragaman SUku dan Budaya Setempat}

1) Keragaman Suku Bangsa. Sekarang kita akan mengenal berbagai macam suku bangsa yang ada dilingkungan kita. Yang dimaksud dengan lingkungan kita disini adalah tetangga-tetangga kita di rumah dan di sekolah. Dalam satu pulau saja, ada beberapa suku bangsa. Dapatkah kamu menyebutkan suku-suku bangsa yang tinggal di Indonesia. Berikut ini contoh suku bangsa yang ada di Indonesia. Suku Bangsa Aceh, Suku Bangsa Batak, Suku Bangsa Minangkabau, Suku Bangsa Melayu, Suku Bangsa Kubu, Suku Bangsa Betawi, Suku Bangsa Sunda dan Suku Bangsa lainnya yang ad adi Indonesia

2) Keragaman Budaya. Kita sudah mempelajari keragaman suku bangsa di Indonesia. Tiap suku bangsa memiliki adat istiadat dan budaya sendiri. Budaya dan adat istiadat daerah dapat kita jumpai dalam hidup sehari-hari. Maka terbentuklah bermacam-macam adat 


$\begin{array}{ll}\text { Volume } & : 05 \\ \text { Nomor } & : 03 \\ \text { Bulan } & : \text { September } \\ \text { Tahun } & : 2019 \\ \text { http } & : \text { //ejurnal.pps.ung.ac.id/index.php/AKSARA/index }\end{array}$

istiadat dan budaya sendiri. Mari kita bahas bentuk-bentuk keragaman budaya bangsa Indonesia dalama aspek-aspek berikut.

3) Bahasa Daerah

Setiap suku bangsa mempunyai bahasa daerah yang khas. Ada bahasa jawa, bahasa minangkabau, bahasa sunda, bahasa batak, bahasa Madura, dan sebagainya.

4) Adat istiadat

Ada bermacam-macam adat istiadat. Contohnya upacara adat yang dipakai waktu orang menikah, waktu orang melahirkan, waktu orang meninggal, dan masih banyak lagi yang lainnya. Kadang-kadang upacara-upacara ini dipadukan dalam agama yang dianut masyarakat. Meskipun berbeda-beda, adat istiadat ini menunjukkan kekayaan budaya yang sangat indah yang dimiliki bangsa Indonesia. Bagaimana dengan adat istiadat di daerahmu? Coba ceritakan bagaimana upacara perkwinan atau kematian di daerahmu. Bagaimana maysrakat di daerahmu menyambut kelahiran bayi, menyelenggarakan upacara pemotongan rambut bayi, sunatan dan sebagainya.

\section{METODE PENELITIAN}

Waktu penelitian dilaksanakan selama dua bulan yakni pada bulan Agustus sampai dengan bulan September tahun 2016. Penelitian ini dilaksanakan pada siswa kelas IV SDN 10 Kabila. Penetapan aspek ini didasarkan pada hasil pengamatan, bahwa sebagian besar siswa belum memahami materi tentang: "Keanekaragaman suku bangsa dan budaya setempat". Oleh karena itu guru dituntut untuk dapat meningkatkan minat siswa dalam memahami dan menghargai suku bangsa dan budaya di lingkungan masyarakat.

Dalam tahap penelitian ini peneliti melakukan langkah-langkah sebagai berikut:

Melakukan konsultasi dengan pihak-pihak yang terkait dengan pelaksanaan penelitian. Disamping itu peneliti melakukan diskusi dengan guru pengamat dan subjek peneliti terutama menyangkut kesiapan mereka untuk diadakan tindakan kelas. Melakukan observasi awal terhadap subyek penelitian. Pengkajian masalah sekaligus observasi dan evaluasi di desain Rencana Pelaksanaan Pembelajaran sesuai dengan tujuan perbaikan yang mengacu pada metode pemberian tugas. Mempersiapkan kelengkapan administrasi pembelajaran serta segala fasilitas dansarana pendukung yang akan dipergunakan di kelas yang dapat menujang pelaksanaan penelitian

Tahap Persiapan Tindakan yaitu: Menyusun jadwal pelaksanaan tindakan, (b) menyusun rencana pelaksanaan pembelajaran (RPP) (c) dan menyiapkan alat bantu dalam pembelajaran, (d) membuat lembaran observasi. Dalam tahap ini, peneliti bersama guru mitra melaksanakan kegiatan sesuai dengan scenario kegiatan yang telah direncanakan dengan menggunakan persiapan pembelajaran yang didalamnya tercakup langkah-langkah pembelajaran yang harus dilakukan guru meningkatkan hasil belajar siswa pada mata pelajaran IPS materi Menghargai Keragaman Suku dan Budaya Setempat dengan menggunakan metode diskusi.

Untuk kepentingan pengumpulan data maka instrument yang digunakan dalam penelitian ini adalah: 1) lembar observasi kegiatan guru. Hal ini dilakukan dalam bentuk tabel dengan menggunakan cek list yang terdiri dari aspek penilaian. Untuk lebih jelasnya dapat dilihat dalam tabel ini berikut ini 


$\begin{array}{ll}\text { Volume } & : 05 \\ \text { Nomor } & : 03 \\ \text { Bulan } & : \text { September } \\ \text { Tahun } & : 2019 \\ \text { http } & : \text { //ejurnal.pps.ung.ac.id/index.php/AKSARA/index }\end{array}$

Tabel 3.1 Lembar Observasi Kegiatan Guru

\begin{tabular}{|l|l|l|l|l|l|}
\hline \multirow{2}{*}{ No } & \multirow{2}{*}{ Aspek yang nilai } & \multicolumn{3}{|c|}{ Tingkat penilaian } & \multirow{2}{*}{ Ket } \\
\cline { 3 - 5 } & & $\mathrm{T}$ & $\mathrm{K}$ & $\mathrm{TT}$ & \\
\hline 1 & Membuat RPP & & & & \\
\hline
\end{tabular}

\begin{tabular}{|l|l|l|l|l|}
\hline Merumuskan tujuan & & & \\
Menyiapkan bahan/alat & & & & \\
demonstrasi & & & & \\
Mendemonstrasi materi & & & & \\
Memberikan evaluasi & & & & \\
\hline
\end{tabular}

$$
\begin{array}{ll}
\text { Keterangan: } \\
\mathrm{T} & \text { : tepat } \\
\mathrm{K} & \text { : Kurang } \\
\mathrm{TT} & \text { : Tidak Tepat }
\end{array}
$$

2) lembar evaluasi kegiatan siswa. Lembar evaluasi motivasi belajar siswa ini dalam bentuk tabel dengan menggunakan cek list yang terdiri atas aspek penilaian dan tingkat penilaian. Untuk lebih jelasnya dapat dilihat pada tabel berikut ini :

Tabel 3.2 Lembar Observasi hasil Belajar Siswa

\begin{tabular}{|l|l|l|l|l|l|l|}
\hline \multirow{2}{*}{ No } & \multirow{2}{*}{$\begin{array}{l}\text { Jumlah } \\
\text { siswa }\end{array}$} & \multirow{2}{*}{ Nilai } & \multirow{2}{*}{ Jumlah } & \multicolumn{4}{|l|}{ Tingkat penilaian } & \\
\cline { 5 - 7 } & & & $\mathrm{R}$ & $\mathrm{C}$ & $\mathrm{T}$ \\
\hline 1 & & & & & \\
\hline 3 & & & & & & \\
\hline & & & & & & \\
\hline
\end{tabular}

$\begin{array}{lll}\text { Keterangan: } & \\ \mathrm{R} & \text { : rendah } & =1-5.4 \\ \mathrm{C} & \text { : cukup } & =5.5-7.4 \\ \mathrm{~T} & \text { : tinggi } & =7.5-10\end{array}$

Pada tahap ini semua data yang diperoleh dari hasil penelitian dan evaluasi dianalisis bersama antara pengamat dan guru secara kualitatif. Hasil analisis digunakan untuk merefleksi diri dan seluruh proses kegiatan. Refleksi yang digunakan adalah untuk mengetahui keberhasilan yang terjadi saat pembelajaran berlangsung. Hasil dari refleksi adlaah diadakannya revisi terhadap perencanaan yang telah dilaksanakan, yang akan digunakan untuk memperbaiki pengelolaan pembelajaran pada siklus berikutnya.

\section{HASIL PENELITIAN DAN PEMBAHASAN Hasil Penelitian}

Berdasarkan hasil penelitian yang telah dilakukan diketahui hasil belajar ssiwa masih rendah yakni sebanyak 25 orang siswa hanya 15 orang atau $58,62 \%$ yang mampu memahami dengan baik, sisanya 10 orang atau $41,37 \%$ belum mampu memahami dengan baik Untuk lebih jelasnya dapat dilihat pad atabel berikut:

Tabel 4.1 Hasil Perolehan Presentase Siswa Siklus I 


$\begin{array}{ll}\text { Volume } & : 05 \\ \text { Nomor } & : 03 \\ \text { Bulan } & : \text { September } \\ \text { Tahun } & : 2019 \\ \text { http } & : \text { //ejurnal.pps.ung.ac.id/index.php/AKSARA/index }\end{array}$

\begin{tabular}{|l|l|l|l|}
\hline No & Jumlah siswa & Persentase & Ket \\
\hline 1 & - & - & Sangat baik $(80-100)$ \\
2 & 9 & $31,03 \%$ & Baik $(70-79,99)$ \\
3 & 8 & $27,58 \%$ & Cukup $(55-69,99)$ \\
4 & 8 & $41,37 \%$ & Kurang $(40-54,99)$ \\
\hline
\end{tabular}

Siklus II

Berdasarkan hasil evaluasi dan refleksi dari guru peneliti pada siklus II ini dilaksanakan perbaikan atas segala kekurangan pada siklus I.

Hasil analisis hasil penerapan metode mengajar pada proses penilaian tetap mengacu pada aspek penelitian pada siklus. Perbaikan terutama diarahkan pada proses peningkatan nilai prestasi belajar siswa, baik secara individu maupun kelompok dengan menciptakan kondisi praktek yang lebih menyenangkan.

\section{PENUTUP}

Berdasarkan kajian teori dan pembahasan yang telah dipaparkan sebelumnya maka dapat disimpulkan sebagai berikut:

Dari hasil refleksi atas kelemahan-kelemahan pembelajaran yang ditemukan pada setiap siklus diharapkan guru secara terbuka untuk menerimanya dan memperbaikinya pada siklus berikutnya sebagai tindak lanjut

Penerapan metode diskusi telah terbukti mampu untuk meningkatkan hasil belajar siswa pada mata pelajaran IPS kelas IV SDN 10 Kabila sehingga diharapkan dapat diikuti oleh mata pelajaran lainnya

\section{DAFTAR PUSTAKA}

Chikahutami.blogspot.com/2012/11/hakekat-tujuan-fungsi-konsep.html

Didaktik Metodik.1998.Surabaya. Usaha Nasional

H. Dinn Wahyudin, D. Supriyadi, Ishak Abdullah.2003. Pengantar Pendidikan. Jakarta. Uniersitas Terbuka

I.G.A.K Wardani, Siti Juleha, Ngadi Marsinah.2008. Pemantapan Kemampuan Profesional. Jakarta. Universitas Terbuka

Mc. Donall. 2000 Interaksi dan motivasi belajar mengajar. Jakarta : Raja Grafindo

Natawidjaya, Rochman 1993. Psikologi Pendidikan. Jakarta Depdikbud Ditjen pendidikan tinggi. Proyek pembinaan tenaga Kependidikan. Jakarta

Pengetahuan Sosial SD Kelas IV. 2007. Jakarta. Erlangga

Penelitian Tindakan Kelas(modul). 2005. Jakarta. Universitas Terbuka

Suradistra, Fakih dan Miftuhi Bunyamin: 1998/1999 Konsep dasar IPS Depdikbud Dirjen pendidikan tinggi Proyek PGSD 